\title{
Selected Bibliography of Statistical Literature 1930 to 1957: V. Frequency Functions, Moments, and Graduation
}

\author{
Lola S. Deming
}

(October 27, 1961)

\begin{abstract}
This is the fifth in a series of bibliographies that deal with various specific subjects in the field of statistics. Over five hundred references and titles of important publications dealing with frequency functions, moments, and graduation are given.
\end{abstract}

The references presented here were extracted from a card file of abstracts clipped from two major reviewing journals in the general fields of probability and mathematical statistics. Zentralblatt für Mathematik was used for the years 1930 to 1939 and Mathematical Reviews was used from 1940 to 1957. Following the subject classification of the Mathematical Reviews Annual Index, the abstracts were classified and coded into categories of subject matter. This bibliography is on frequency functions, moments, and graduation.

The file of abstracts is maintained on a current basis in the NBS Statistical Engineering Laboratory. However, due to the delay in classifying, coding, and machine processing the references, this series of bibliographies extends only through 1957. The two reviewing journals cover a wide range of publications throughout the world but they do make a selection of material for review and in the case of mathematical statistics, they favor papers of theoretical significance over the ones which deal chiefly with applications. Consequently, complete coverage is not claimed but we believe that references to a useful number of writings of major statistical importance are given.

The references contain the following information taken directly from the abstracts:

Author: The author's surname, followed by initials only. In the case of multiple authorships, the journal reference appears with each author's name, but the title of the paper appears with the first author only. The symbol $\downarrow$ preceding the surname denotes multiple authorship.

Title: Exactly as in the reviewing journal. Titles of separately bound publications (books, reports, theses, etc.) are in italics, followed by the publisher.

Reference to literature: The name of the journal in italies, the number of the volume in bold face, the initial page number, and the date of publication in parentheses comprise the reference to the original article.

Reference to the abstract: The final symbols $M$ (for Mathematical Reviews) and $Z$ (for Zentralblatt für Mathematik) are followed by the volume number and page number of the reviewing journal in which the abstract appears.

\section{Frequency Functions, Moments, Graduation}

Agnew, R. P., Estimates for global central limit theorems, Ann. Math. Statist. 28, 26 (1957).

M 18, 832

Aitken, A. C., On Charlier's new form of the frequency function, Proc. Roy. Soc., Edinburgh 51, 35 (1931).

Z 2,43

Aitken, A. C., Note on selection from a multivariate normal population, Proc. Edinburgh Math. Soc. 4, $106(1935)$

Z 10, 406

Aitken, A. C., A further note on multivariate selection, Proc. Edinburgh Math. Soc. 5, 37 (1936).

Z 15, 220

Aitken, A. C., On the independence of linear and quadratic forms in samples of normally distributed variates, Proc. Roy. Soc., Edinburgh 60, 40 (1940).

M 1, 346

Aitken, A. C., On the estimation of statistical parameters, Proc. Roy. Soc., Edinburgh A 61, 186 (1942).

M 4, 25

Alter, D., Correction of sample moment bias due to lack of high contact and to histogram grouping, Ann. Math. Statist. 10, 192 (1939).

Z $\mathbf{2 3}, 149$

Amy, L., Etude statistique de l'expression, $p_{1} / q_{1}=$ $\mathrm{p}_{2} / \mathrm{q}_{2}=\ldots=\mathrm{p}_{1} / \mathrm{q}_{1}=\mathrm{C}^{\mathrm{te}}, J$. Soc. Statist, Paris, 81, 39 (1940) M 10, 722

Andersson, W., A general formula for the normal mean errors of the coefficients in parabolic least squares graduation, Skand. Aktuarietidskr. 23, 44 (1940). M 2, 109

Andersson, W., The binomial type of Gram's series, Skand. Aktuarietidskr. 24, 203 (1941). M \%, 247

Andersson, W., On the Gram series on Pearson's system of frequency functions, Skand. Aktuarietidskr. 25, 141 (1942).

M $\boldsymbol{\%}, 248$

Andersson, W., Short notes on Charlier's method for expansion of frequency functions in series, Skand. Aktuarietidskr. 2\%, 16 (1944).

M $\boldsymbol{\%}, 248$

Andreoli, G., Statistica degli aggregati in una collettività e concentrazione rispetto a due caratteri, Rend. Accad. Sci. Fis. Mat. Napoli 10, 160 (1940).

M 8, 523

Andreoli, G., Statistica di configurazioni (Ricerche su coppie di variabili casuali in correlazione), Rend. Accad. Sci. Fis. Mat. Napoli 11, 150 (1941).

M 8, 523 
Andrews, F. C., (See Z. W. Birnbaum) Ann. Math. Statist. 20, 458 (1949).

Andrews, F. C., (See Z. W. Birnbaum) Psychometrika 15, 191 (1950).

Anis, A. A., On the moments of the maximum of partial sums of a finite number of independent normal variates, Biometrika 43, 79 (1956).

M 1\%, 981

Arley, N., On the distribution of relative errors from a normal population of errors. A discussion of some problems in the theory of errors, Danske Vid. Selsk. Math.-Fys. Medd. 18, 62 pp. (1940).

M 2, 232

Aroian, L. A., The fourth degree exponential distribution function, Ann. Math. Statist. 19, 589 (1948).

M 10, 386

Austen, A. E. W., Linear 'curves of best fit,' Nature 15\%, 693 (1946).

M 8, 40

Azorín, F., On peakedness and its measure, Trabajos Estadistica 1, 263 (1950).

M 13, 366

Bailey, J. L., A table to facilitate the fitting of certain logistic curves, Ann. Math. Statist. 2, 355 (1931).

$\mathrm{Z}$ 4, 265

Banerjee, D. P., On the moments of the multiple correlation coefficient in samples from normal population, J. Indian Soc. Agric. Statistics 4, 88 (1952).

M 14, 189

Banerjee, D. P., On the application of operational calculus to the solution of distribution problems, Acad. Roy. Belg. Bull. Cl. Sci. (5) 42, 437 (1956).

M 1\%, 1221

Banerjee, K. S., (See K. R. Nair) Sankhyā 6, 331 (1943).

Baranow, L., Grundbegriffe moderner statistischer Methodik. Erster Teil. Merkmalsverteilungen. (S. Hirzel Verlag, Stuttgart, 1950). M 12, 35

Baranow, L., Grundbegriffe moderner statistischer Methodik. Zweiter Teil. Zeitliche und kausale Zusammenhänge (S. Hirzel Verlag, Stuttgart, 1950).

M 12, 35

Bartlett, M. S., A modified probit technique for small probabilities, Suppl. J. Roy. Statist. Soc. 8, 113 (1946).

M 8, 283

Bartlett, M. S., Fitting a straight line when both variables are subject to error, Biometrics 5, 207 (1949).

M 11, 190

-Barton, D. E., The conditions under which GramCharlier and Edgeworth curves are positive definite and unimodal, Biometrika 39, 425 (1952).

M 14, 389

Baten, W. D., Correction for the moments of a frequency distribution in two variables, Ann. Math. Statist. 2, 309 (1931).

$\mathrm{Z}$ 4, 264

Baten, W. D., Sampling from many parent populations, Tôhoku Math. J. 36, 206 (1933). Z Z 6, 268

Baten, W. D., A formula for finding the skewness of the combination of two or more samples, J. Amer. Statist. Assoc. 30, 95 (1935).

$\mathrm{Z} \mathbf{1 1}, 126$

Baticle, E., Sur une loi de probabilité a priori des paramètres d'une loi laplacienne, C.R. Acad. Sci., Paris 226, 55 (1948).

M 9, 294

Baumberger, A., Uber Verteilungsfunktionen in der Kollektivmasslehre, Bern: Diss. 66 S. (1938).

Z 22, 371
Bay, Z., Statistical theory of delayed-coincidence experiments, Phys. Rev. 100, 1197 (1955).

M 17, 506

Beale, F. S., On a certain class of orthogonal polynomials, Ann. Math. Statist. 12, 97 (1941).

M R, 282

Béjar, J., Maxima and minima of the coefficients of asymmetry and kurtosis in finite populations, Trabajos Estadistica 3, 3 (1952).

M 14, 389

$\checkmark$ Bellinson, H. R., (See J. von Neumann) Ann. Math. Statist. 12, 153 (1941).

$\checkmark$ Benard, A., The plotting of observations on probability paper, Statistica (Rijswijk) \%, 163 (1953).

M 15, 807

Benedetti, C., Sulla rappresentabilità di una distribuzione binomiale mediante una distribuzione $B$ e vice-versa, Metron 18, 121 (1956). $\quad$ M 18, 606

Benjamin, K., An I.B.M. technique for the computation of $\Sigma \mathrm{X}^{2}$ and $\Sigma \mathrm{XY}$, Psychometrika 10, 61 (1945).

M 6, 220

Bennett, B. M., The cumulants of a sample mean from a finite population of first $N$ integers, Trabajos Estadistica 6, 31 (1955).

M 1\%, 380

Bennett, B. M., On the cumulants of the logarithmic generalized variance and variance ratio, Skand. Aktuarietidskr. 38, 17 (1955).

M 1\%, 638

Berger, A., Zur Theorie der Berechnung von Versicherungswerten für mehrere verbundene Leben, Bl. Versich. Math. 2, 371 (1933).

Z 6, 175

Berger, A., Über den Einfluss einer Änderung der Rechnungsgrundlagen auf die Prämienreserven, Mitt. Vereinig Schweiz. Versich.-Math H 32, 7 (1936).

$\mathrm{Z}$ 15, 262

Berkson, J., Approximation of chi-square by "probits" and by "logits," J. Amer. Statist. Assoc. 41, 70 (1946).

M $\boldsymbol{7}, 462$

Bernstein, F., Säkulare Sterblichkeitsänderung und Prinzip der Gewinnverteilung mittels einer Höcknerschen Überschusskonstanten $\lambda, B l$. Versich. Math. 2, 390 (1933).

$\mathrm{Z}$ 6, 175

Bhattacharyya, B. C., The use of McKay's Bessel function curves for graduating frequency distributions, Sankhyā 6, 175 (1942).

M 5, 126

Bhattacharyya, B. C., On an aspect of Pearsonian system of curves and a few analogies, Sankhyā 6, 415 (1944).

M 6, 8

Bhattacharyva, B. C., On a measure of divergence between two multinomial populations, Sankhyāy, 401 (1946).

M 8, 282

Birnbaum, Z. W., On random variables with comparable peakedness, Ann. Math. Statist. 19, 76 (1948).

M 9, 452

-Birnbaum, Z. W., On sums of symmetrically truncated normal random variables, Ann. Math. Statist. 20, 458 (1949).

M 11, 41

-Birnbaum, Z. W., On the effect of selection performed on some coordinates of a multi-dimensional population, Psychometrika 15, 191 (1950).

M 12, 36

Blanc, C., Évaluation stochastique de l'erreur dans les formules d'intégration numérique, $C . R$. Acad. Sci., Paris 233, 726 (1951). M13, 368 
Blane, C., Évaluation stochastique de l'erreur dans les formules d'interpolation, $C$. R. Acad. Sci., Paris 233, 683 (1951).

M 13, 368

Blanche, E. E., A systematic analysis of frequency distributions by the Edgeworth method, (Thesis, University of Illinois, 1941).

M 11, 258

Blümel, H., Bemerkungen über die Sheppardsche Korrektur, Arch. Math. Wirtsch. U. Sozialforschg. 5, 39 (1939).

Z 20, 383

Boas, R. P., The Charlier B-series, Trans. Amer. Math Soc. 6\%, 206 (1949).

M 11, 173

Boas, R. P., Representation of probability distributions by Charlier series, Ann. Math. Statist. 20, 376 (1949).

M 11, 190

Boldrini, M., Sulla theoria della media tipica, Pont. Acad. Sci. Comment. 10, 1 (1946).

M 10, 50

Bonferroni, Co., I valori mediani in una disribuzione continua, Statistica (Bologna) 15, 3 (1955).

M 16, 1037

Bortkiewicz, L., The relations between stability and homogeneity, Ann. Math Statist. 2, 1 (1931).

$\mathrm{Z}$ 4, 408

Bose, P., On the reduction formulae for the incomplete probability integral of the multiple correlation coefficient of the second kind, Science and Culture $\boldsymbol{\gamma}, 171$ (1941).

M $\mathbf{5}, 42$

Bose, P., Certain moment calculations connected with multivariate normal populations, Science and Culture \%, 411 (1942).

M $\mathbf{5}, 42$

Bose, P. K., Corrigenda: On the construction of incomplete probability integral tables of the classical D²-statistic, Sankhyā 11, 96 (1951).

M 13, 52

-Bos-Levenbach, E. C., (See A. Benard) Statistica (Rijswijk) \%, 163 (1953).

Brelot, M., Sur l'influence des erreurs de mesure en statistique, J. Math. pures appl. 15, 113 (1936).

$\mathrm{Z} \mathrm{14,} 121$

Brelot, M., Sur l'influence des erreurs de mesure en statistique et biométrie, Extrait Bull. Trav. Publ. Stat. Aquicult. et Pêche Castiglione, 44 pp. (1936).

Z 14, 169

Brethouwer, D. H. G., The hyperbolic law of errors, Statistica (Rijswijk) R, 55 (1948).

M 11, 258

Broadbent, S. R., Lognormal approximation to products and quotients, Biometrika 43, 404 (1956).

M 18, 340

Brown, G. M., On sampling from compound populations, Ann. Math. Statist. 4, 288 (1933). Z 8, 217

Brown, L. M., Some parameters of sampling distributions simply obtained, Edinburgh Math. Notes No. 34, 8 (1944).

M 6, 91

$\checkmark$ Bruner, N., (See G. R. Davies) J. Amer. Statist. Assoc. 38, 63 (1943).

Bula, C. A., Das Problem der Interpolation in der Statistik, Rev. Un. Mat. Argentina 2, 1 (1938).

Z 22, 63

Bula, C. A., Theory and evaluation of central moments in two dimensions. Sheppard's corrections. The simpler method of Mitropolsky, Rev. Un. Mat. Argentina 5, 1 (1940). M 2, 231

Bula, C. A., Calculation of frequency surfaces. Experimental verification and comparison of the method of marginal functions with that of the 15 constants of Karl Pearson, Union Mat. Argentina, Publ. No. 10, 109 pp. (1940).

M 3, 170

Burkhardt, F., Zur Ableitung der Sheppardschen Korrektur, Arch. Math. Wirtsch. u. Sozialforschg. 5, 127 (1939).

$\mathrm{Z} \boldsymbol{2 1}, 146$

Burr, I. W., Cumulative frequency functions, Ann. Math. Statist. 13, 215 (1942).

M 4, 19

Burr, I. W., Calculation of exact sampling distribution of ranges from a discrete population, $A n n$. Math. Statist. 26, 530 (1955).

M 17, 278

Burrau, C., The half-invariants of the sum of two typical laws of errors, with an application to the problem of dissecting a frequency curve into components, Skand. Aktuarietidskr. 1\%, 1 (1934).

Z 8, 368

Burrau, O., The mean error as a measure of uncertainty, Mat. Tidsskr. B 1943, 9 (1943). M $\quad$ g, 130

Burrau, O., On the determination of the mean error, Mat. Tidsskr. B 1945, 97 (1945). $\quad$ M $\%, 211$

Busk, T., Some remarks on the computation of the mean error for values graduated by the method of least squares, (Den Danske Aktuarforening, Copenhagen, 1943).

M 8, 40

Campbell, J. T., Factorial moments and frequencies of Charlier's type B, Proc. Edinburgh Math. Soc. 3, 99 (1932).

Z 5, 213

Cansado, E., Integral de Stieltjes-Lebesgue y sus Aplicaciones a la Estadística, Memorias de Matematica Instituto Jorge Juan, No. 3, 66 pp. (Madrid, 1946).

Cansado, E., On the factorial characteristic function, Revista Mai. Hisp. Amer., 159 (1947). M 9, 283

Cansado, E., On the compound and generalized Poisson distributions, Ann. Math. Statist. 19, 414 (1948).

M 10, 552

Cansado, E., On the application of the moment generating function to unrestricted random sampling, Trabajos Estadistica 1, 117 (1950).

M 13, 570

Carpenter, O., Note on the extension of Craig's theorem to non-central variates, Ann. Math. Statist. 21, 455 (1950).

M 12, 621

Carver, H. C., Fundamentals of sampling, Ann. Math. Statist. 1, 101 (1930).

Carver, H. C., The fundamental nature and proof of Sheppard's adjustments, Ann. Math. Statist. \%, 154 (1936).

Castellano, V., Sulle relazioni tra curve di frequenza e curve di concentrazione e sui rapporti di concentrazione corrispondenti a determinate distribuzioni, Metron 10, 3 (1933). Z 6, 267

Castellano, V., Recente letteratura sugli indici di variabilità, Metron 12, 101 (1935). Z 12, 411

Castellano, V., Sugli indici relativi di variabilità e sulla concentrazione dei caratteri con segno, Metron 13, 31 (1937).

Z 16, 67

Castellano, V., Über die Wahrscheinlichkeit, dass zwei Stichproben voneinander mehr als zwei gegebene Verteilungen abweichen. Anhang I zu dem Aufsatz von C. Gini, Die Messung der Ungleichheit zweier Verteilungen, Arch. Math. Wirtsch. u. Sozialforschg. 3, 184 (1937). Z 17, 274 
Castellano, V., Sulle variabili divise in intervalli e le correzioni della media aritmetica e della varianza, Statistica (Bologna) 16, 151 (1956). M 18, 520

Castoldi, L., Formule ricorrenti per il calcolo dei cumulanti e dei momenti di una distribuzione statistica a partire dai corrispondenti momenti fattoriali, Rend. Sem. Fac. Sci. Univ. Cagliari $\mathbf{2 4 ,}$ 157 (1955).

M 1\%, 52

Cell, J. W., An accurate method for obtaining the derivative function from observational data, Amer. Math. Monthly 46, 87 (1939).

Z $\mathbf{2 1}, 242$

Chakrabarti, M. C., A note on skewness and kurtosis, Bull. Calcutta Math. Soc. 38, 133 (1946). M 8, 393

Chakrabarti, M. C., On a special case of the distribution law of the mean square successive difference, Bull. Calcutta Math. Soc. 39, 15 (1947). M 9, 195

Chakrabarti, M. C., On the inadequacy of measuring the peakedness of a distribution curve by the standardized fourth moment, Bull. Calcutta Math. Soc. 39, 154 (1947).

M 10, 50

-Chakraborty, P. N., (See C. Chandra Sekar) Sankhyā 1\%, 141 (1952).

Chanda, K. C., On some moment properties when two polynomials have independent distributions, Calcutta Statist. Assoc. Bull. 6, 40 (1955).

M 16, 1131

- Chandra Sekar, C., On the concept and use of orthogonal semi-polynomials, Sankhyā 1\%, 141 (1952).

M 14, 995

Chapman, D. G., Estimating the parameters of a truncated gamma distribution, Ann. Math. Statist. 2\%, 498 (1956).

M 1\%, 1221

Charnler, F., The variances of the means and the variance of the slope of the line of relation of a linear, composite, bivariate distribution, Canadian J. Research, Sect. A 20, 6 (1942).

M 3, 172

Cheng, T. T., A simplified formula for mean difference, Coll. Papers Sci. Engin. Nat. Univ. Amoy 1, 69 (1943)

M 8, 160

Cheng, T. T., A simplified formula for mean difference, J. Amer. Statist. Assoc. 39, 240 (1944).

M 6, 91

Chepelevski, A., Sur la critique des courbes de fréquence de Pearson, J. Cycle Math. 2, 1 (1932).

Z 6, 268

Choudhary, N. A., A generalization of binomial, Lexian and Poisson distributions, Math. Student 15, 8 (1948).

M 10, 386

-Chu, J. T., The moments of the sample median, Ann. Math. Statist. 26, 593 (1955). M 1\%, 502

Chu, J. T., Errors in normal approximations to the $t, \tau$, and similar types of distribution, Ann. Math. Statist. 28, 780 (1956).

M 18, 423

Churchill, E., Information given by odd moments, Ann. Math. Statist. 1\%, 244 (1946).

M 8, 153

Cisbani, R., Contributi alla teoria delle medie, Metron 13, 23 (1938).

Z 18, 266

Cisbani, R., Contributi alla teoria delle medie. II, Metron 13, 3 (1938).

Z 20, 148

Cochran, W. G., The distribution of the largest of a set of estimated variances as a fraction of their total, Ann. Eugenics 11, 47 (1941).

M 3, 171

Cohen, A. C., On estimating the mean and standard deviation of truncated normal distributions, $J$. Amer. Statist. Assoc. 44, 518 (1949).

M 11, 258

Cohen, E. R., The basis for the criterion of least squares, Rev. Modern Physics \%5, 709 (1953).

M 15, 543

Cohen, E. R., Standard errors of the residues in a least-squares analysis, Phys. Rev. 101, 1641 (1956).

M 1\%, 981

Cook, M. B., Bi-variate $k$-statistics and cumulants of their joint sampling distribution, Biometrika 38, 179 (1951).

M 13, 142

Craig, C. C., On a property of the semi-invariants of Thiele, Ann. Math. Statist. \%, 154 (1931). Z 5, 256

Craig, C. C., A new exposition and chart for the Pearson system of frequency curves, Ann. Math. Statist. \%, 16 (1936).

Z 13, 359

Craig, C. C., Sheppard's corrections for a discrete variable, Ann. Math. Statist. y, 55 (1936). Z 15, 33

Craig, C. C., The product semi-invariants of the mean and a central moment in samples, Ann. Math. Statist. 11, 177 (1940). M 1, 346

Craig, C. C., A note on Sheppard's corrections, Ann. Math. Statist. 12, 339 (1941). M 3, 171

Craig, C. C., On frequency distributions of the quotient and of the product of two statistical variables, Amer. Math. Monthly 49, 24 (1942).

M 3, 171

Cramér, H., Deux conférences sur la théorie des probabilitiés, Skand. Aktuarietidskr, 24, 34 (1941).

M 3, 169

Cramér, H., Mathematical methods of statistics, (Princeton University Press, Princeton, N.J., 1946).

M 8, 39

Crow, J. F., A chart of the $\chi^{2}$ and $t$ distributions, J. Amer. Statist. Assoc. 40, 376 (1945). M g, 20

Curtiss, J. H., Generating functions in the theory of statistics, Amer. Math. Monthly 48, 374 (1941).

M 3, 5

Curtiss, J. H., A note on the theory of moment generating functions, Ann. Math. Statist. 13, 430 (1942).

M 4, 163

D’Addario, R., Un metodo per la rappresentazione analitica delle distribuzioni statistiche, Atti. Ist. Naz. Assicuraz. 1\%, 93 (1940).

M 11, 190

Daniels, H. E., A property of the distribution of extremes, Biometrika 32, 194 (1941). M 3, 171

Darmois, G., Détermination de la moyenne et de la dispersion dans le cas des épreuves dependantes, Assoc. Franc. Advancement Sci., pp. 34-37 (55th session, Nancy, 1931).

Z 6, 121

David, F. N., On Neyman's "smooth" test for goodness of fit. I. Distribution of the criterion $\psi^{2}$ when the hypothesis tested is true, Biometrika 31, 191 (1939).

M 1, 153

David, F. N., Probability theory for statistical methods, (Cambridge University Press, 1949). M 10, 613

David, F. N., The probability integral transformation when the variable is discontinuous, Biomeirika 3\%, 42 (1950).

M 1\%, 115

- David, F. N., Reciprocal Bernoulli and Poisson variables, Metron 18, 77 (1956).

M 18, 520

David, H. A., An operational method for the deriva- 
tion of relations between moments and cumulants, Metron 16, 41 (1952).

M 14, 486

David, H. A., Moments of negative order and ratiostatistics, J. Roy. Statist. Soc., Ser. B 1\%, 122 (1955).

M 1\%, 278

-Davies, G. R., A second moment correction for grouping, J. Amer. Statist. Assoc. 38, 63 (1943).

M 4, 221

Dehalu, M., Sur la démonstration de la formule de $\mathrm{K}$. Pearson dans le cas du schéma simple des urnes, Bull. Soc. Roy. Sci. Liége 11, 146 (1942). M, 20

- Dehara, S., (See T. Kudō) J. Gakugei Tokushima U. Nat. Sci. Math. 6, 75 (1955).

Delgleize, A., Sur le schéma simple des urnes, Bull. Soc. Roy. Sci. Liége 11, 398 (1942).

M 8,20

Delgleize, A., Sur les courbes de fréquence, Bull. Soc. Roy. Sci. Liége 1\%, 264 (1943).

M $\%, 20$

Della Riccia, A., Courbes de fréquence et courbes de distribution. Une généralisation de la loi de Gauss, Ann. Soc. Sci. Bruxelles A 54, 133 (1934).

Z 10, 313

Deming, W. E., On a least squares adjustment of a sampled frequency table when the expected marginal totals are known, Ann. Math. Statist. 11, $427(1940)$.

M $\boldsymbol{*}, 232$

Deming, W. E., Statistical adjustment of data, John Wiley \& Sons Inc., N.Y., 1943).

M 5, 208

-Dennis, K. E., (See D. E. Barton) Biometrika 39, 425 (1952).

Derksen, J. B. D., On some infinite series introduced by Tschuprow, Ann. Math. Statist. 10, 380 (1939).

M 1, 152

Dieulefait, C. E., Verallgemeinerung der Pearsonschen Kurven, An. Soc. Ci. Argent. 115, 194 (1933).

Z 9, 314

Dieulefait, C. E., Généralisation des courbes de K. Pearson, Metron 1\%, 95 (1935)

Z 11, 361

Dieulefait, C., On the Poisson-Charlier series, $A n$. Soc. Ci. Argentina 128, 10 (1939).

M 1, 143

Dieulefait, C., On a result of Prof. Beppo Levi and its relation to the problem of frequency surfaces, An. Soc. Ci. Argentina 129, 249 (1940). M 3, 171

Dodd, E. L., Classification of sizes or measures by frequency functions, J. Amer. Statist. Assoc. 26, 227 (1931).

Z 2,280

Dodd, E. L., Frequency laws showing stability with reference to the geometric mean and other means, Bull. Amer. Math. Soc. 38, 398 (1932). Z 5, 111

Dodd, E. L., Internal and external means arising from the sealing of frequency functions, $A n n$. Math. Statist. 8, 12 (1937).

Z 16, 365

Dodd, E. L., Definitions and properties of the median, quartiles, and other positional means, Amer. Math. Monthly 45, 302 (1938).

Z 18, 415

Dodd, E., Some internal and external means arising from the location of frequency distributions, Acta. Univ. Asiae Mediae $\mathbf{8 3}, 8$ pp. (1939). M 8, 523

Dodd, E. L., The substitutive mean and certain subclasses of this general mean, Ann. Math. Statist. 11, 163 (1940).

M 1, 345

Dodd, E. L., The cyclic effects of linear graduations persisting in the differences of the graduated values, Ann. Math. Statist. 1\%, 127 (1941).

M 3, 10
Dodd, E. L., Some generalizations of the logarithmic mean and of similar means of two variates which become indeterminate when the two variates are equal, Ann. Math. Statist. 1\%, 422 (1941).

M 3, 170

Dodd, E. L., Lectures on probability and statistics, (University of Texas Press, Austin, Texas, 1945).

M $\%, 130$

Dommanget, J., Etude des droites caractérisant soit une liaison fonctionnelle, soit une dépendance statistique entre deux variables, Publ. Sci. Tech. Ministère de l'Air, Technical Notes No. 52, 2939, Paris (1955).

M 16, 1040

Doob, J. L., Probability and statistics, Trans. Amer. Math. Soc. 36, 759 (1934).

Z 10, 173

Dressel, P. L., Statistical semivariants and their estimates with particular emphasis on their relation to algebraic invariants, Ann. Math. Statist. 11, 33 (1940).

M 1, 249

Dressel, P. L., A symmetric method of obtaining unbiased estimates and expected values, Ann. Math. Statist. 1\%, 84 (1941).

M $\boldsymbol{2}, 233$

Drion, E. F., Estimation of the parameters of a straight line and of the variances of the variables, if they are both subject to error, Nederl. Akad. Wetensch. Proc. Ser. A 54, 256 (1951). M 13, 144

Dugué, D., Sur certaines composantes des lois de Cauchy, C. R. Acad. Sci., Paris 213, 718 (1941).

M 5, 124

Dugué, D., Sur un nouveau type de courbe de frèquence, C. R. Acad. Sci., Paris 213, 634 (1941).

M 5, 126

Dumas, M., Sur les courbes de fréquence de K. Pearson, Biometrika 35, 113 (1948). M 9, 599

Durbin, J., Errors in variables, Rev. Inst. Internat. Statist. 2\%, 23 (1954).

M 18, 52

Dwyer, P. S., Moments of any rational integral isobaric sample moment function, Ann. Math. Statist. 8, 21 (1937).

Z 16, 313

Dwyer, P. S., Combined expansions of products of symmetric power sums and of sums of symmetric power products with application to sampling, Ann. Math. Statist. 9, 1 (1938). Z 18, 415

Dwyer, P. S., The cumulative numbers and their polynomials, Ann. Math. Statist. 11, 66 (1940).

M 1, 345

Dwyer, P. S., Grouping methods, Ann. Math. Statist. 13, 138 (1942).

M 4, 24

Dwyer, P. S., Combinatorial formulas for the $r$ th standard moment of the sample sum, of the sample mean, and of the normal curve, Ann. Math. Statist. 11, 353 (1940).

M \%, 109

Dyson, F. J., A note on kurtosis, J. Roy. Statist. Soc. 106, 360 (1943).

M 6, 162

Edgett, G. L., Frequency distributions with given statistics which are not all moments, Metron 9, 25 (1931).

Z ?, 280

Eìdel'nant, M. I., Round-off errors, Akad. Nauk Uzbek. SSR. Trudy Inst. Mat. Meh. 11, 63 (1953).

M 1\%, 871

Eisenring, M., (See H. Jecklin) Mitt. Verein. Schweiz. Versich-Math. 47, 123 (1947). 
Elderton, W. P., Adjustments for moments of Jshaped curves, Biometrika 25, 179 (1933).

Elfving, G., An expansion principle for distribution functions with application to Student's statistic, Ann. Acad. Sci. Fenn. Ser. A. 1, No. 204, 8 pp. (1955).

M 1\%, 981

Epstein, B., Some applications of the Mellin transform in statistics, Ann. Math. Statist. 19, 370 (1948).

M 10, 552

Evans, W. D., Note on the moments of a binomially distributed variate, Ann. Math. Statist. 11, 106 (1940).

M 1, 247

Evans, W. D., The standard error of percentiles, J. Amer. Statist. Assoc. 3\%, 367 (1942). M 4, 103

Eyraud, H., Valori osservati di una variabile casuale e loro perequazione, Giorn. Ist. Ital. Attuari. 6, 243 (1935).

Z 12, 113

Eyraud. H., Sur certaines décompositions en aléatoires imaginaires, C. R. Acad. Sci. Paris 206, 723 (1938).

Z 18, 155

Eyraud, H., Les lois d'erreurs dans deux dimensions, Ann. Univ. Lyon, Sect. A 2, 19 (1939). M 8, 282

Faleschini, L., Su alcune proprietà dei momenti impiegati nello studio della variabilità, asimmetria e curtosi, Statistica (Milano) 8, 503 (1948).

M 11, 445

Feldheim, E., Sul rapporto fra la media dei quadrati di più errori e il quadrato della media dei loro valori assoluti, Atti. Accad. Sci. Torino Cl. Sci. Fis. Mat. Nat. $\mathbf{5 5}, 296$ (1940).

M 3, 6

Feldman, H. M., Mathematical expectation of product moments of samples drawn from a set of infinite populations, Ann. Math. Statist. 6, 30 (1935).

Z 11, 317

Feraud, L., Problème d'analyse statistique à plusieurs variables, Ann. Univ. Lyon, Sect. A 5, 42 (1942).

M 8, 282

Feraud, L., Statistique mathématique: Distributions de produits, intérieurs, $C$. R. Séances Soc. Phys. Hist. Nat., Genève 60, 196 (1943). M \%, 212

Féron, R., De l'information, C. R. Acad. Sci., Paris 230, 1495 (1950).

$\mathrm{M}$ 11, 732

de Finetti, B., Sui metodi proposti per il calcolo della differenza media, Metron 9, 47 (1931).

Z 2, 199

Finney, D. J., The joint distribution of variance ratios based on a common error mean square, Ann. Eugenics 11, 136 (1941).

M 3, 172

Finney, D. J., Probit Analysis. A Statistical Treatment of the Sigmoid Response Curve (Cambridge Univ. Press, England, or Macmillan Co., New York, 1947). xiii +256 pp. M 8, 592

Fisher, R. A., Professor Karl Pearson and the method of moments, Ann. Eugenics \%, 303 (1937).

Fisher, R. A., The negative binomial distribution, Ann. Eugenics 11, 182 (1941). M 4, 26

Fisher, R. A., Note on the efficient fitting of the negative binomial, Biometrics 9, 197 (1953).

M 14, 1104

Fisher, W. D., On a pooling problem from the statistical decision viewpoint, Econometrica 21, 567 (1953).

M 15, 452

Fogelson, S., Quelques remarques sur les courbes de concentration, Ann. Univ. Lyon, Sect. A, Sci. Math. et Astron. 1, 69 (1936). Z 15, 220

Fortunati, P., Appunti sulle misure statistiche della variabilità, Statistica (Bologna) 12, 297 (1952).

M 14, 568

Franckx, E., Sur les fonctions de fréquence de $n$ variables. Relation générale entre les moments et les semi-in-variants, Aktuár. Vedy 6, 163 (1937).

$\mathrm{Z}$ 1\%, 77

Fréchet, M., Sur une limitation très générale de la dispersion de la médiane, J. Soc. Statist. Paris 81, 67 (1940).

M 10, 722

Fréchet, M., Sur la correpondance entre certaines lois d'erreurs et certaines définitions de la distance, Revue Sci. 79, 3 (1941).

M $\boldsymbol{\gamma}, 20$

Fréchet, M., Sur une loi de probabilité considérée par J. F. Steffensen, Skand. Aktuarietidskr. 24, 214 (1941).

M $\%, 211$

Fréchet, M., A general method of constructing correlation indices, Proc. Math. Phys. Soc. Egypt 3, 13 (1946).

M 8, 592

Fréchet, M., Definition of the probable deviation, Ann. Math. Statist. 18, 288 (1947). $\quad$ M 8, 592

Fréchet, M., Les valeurs typiques d'ordre nul ou infini d'un nombre aléatoire, Rev. Inst. Internat. Statistique 16, 1 (1948).

M 11, 40

- Freeman, M. F., Transformations related to the angular and the square root, Ann. Math. Statist. 21, 607 (1950).

M 12, 344

Fuhrich, J., Über eine allgemeine Methode zur mathematischen Analyse empirischer Reihen, $M h$. Math. Phys. 44, 307 (1936).

$\mathrm{Z}$ 15, 73

Gabriel, F., Graphisch-rechnerisches Verfahren zur schnellen Ermittlung von Trefferprozenten unter einfachen und erschwerten Bedingungen. "Trefferspinne." Luftfahrtforschung 19, 231 (1942).

M 4, 103

Gaddum, J. H., Lognormal distributions, Nature 156, 463 (1945).

M $\boldsymbol{y}, 211$

Gallina, G., Un teorema sul problema delle prove ripetute, Boll. Un. Mat. Ital. 11, 206 (1932).

Z 5, 213

Galvani, L., Sulle curve di concentrazione relative a caratteri non limitati e limitati, Metron 10, 61 (1932).

$\mathrm{Z} \mathrm{5,} 256$

- Geary, R. C., Tests of normality, (Cambridge University Press, 1938) 15 pp.

Z 19, 74

Geary, R. C., Inherent relations between random variables, Proc. Roy. Irish Acad. Sect. A 4\%, 63 (1942).

M 4, 21

Geiringer, H., Une méthode générale de statistique théorique, C. R. Acad. Sci., Paris 198, 420 (1934).

Z 8, 265

Geiringer, H., Applications d'une nouvelle méthode générale de statistique théorique, C.R. Acad. Sci., Paris 198, 696 (1934).

Z 8, 368

Geiringer, H., Une nouvelle méthode de statistique théorique (problèmes à deux dimensions), Bull. Acad. Roy. Belg. V. s. 21, 157 (1935). Z 11, 218

Geiringer, H., Une nouvelle méthode de statistique théorique (problèmes à deux dimensions), II, Bull. Acad. Roy. Belg. V. s. 21, 307 (1935).

Z 11, 218 
Geiringer, H., Methoden der theoretischen Statistik, Compositio Math. 2, 276 (1935).

Z 12, 112

Geiringer, H., Zur Verwendung der mehrdimensionalen Normalverteilung in der Statistik, $M h$. Math. Phys. 43, 425 and 44, 97 (1936). Z 14, 222

Geiringer, H., A new explanation of nonnormal dispersion in the Lexis theory, Econometrica 10, 53 (1942).

M 3, 173

Geisser, S., A note on the normal distribution, Ann. Math. Statist. 2\%, 858 (1956).

M 18, 240

Georgescu, N., Further contributions to the sampling problem, Biometrika 24, 65 (1932). Z 5, 111

Gini, C.., Di una formula comprensiva delle medie, Metron 13, 3 (1938).

Z 18, 414

-Gini, C., Sulle proprietà delle medie potenziate e combinatorie, Metron 13, 21 (1938). Z 20, 148

Gini, C., Le medie dei campioni, Metron 15, 13 $(1949)$.

M 11, 446

Gini, C., L'evoluzione del concetto di media, Metron 16, 3 (1952).

M 14, 486

Gini, C., Estensione della teoria della dispersione e della connessione a serie di grandezze assolute, Giorn. 1st. Ital. Attuari. 15, 4 (1952). M 16, 54

Gini, C., Estensioni e portata della teoria della dispersione, Studies in Mathematics and Mechanics presented to R. von Mises, pp. 323-335 (Academic Press Inc., New York 1954).

M 16, 381

Gonin, H. T., The use of factorial moments in the treatment of the hypergeometric distribution and in tests for regression, Philos. Mag. VII 21, 215 (1936).

Z 13, 273

Gonin, H. T., Curve fitting by means of the orthogonal polynomials in binomial statistical distributions, Trans. Roy. Soc. South Africa 30, 207 (1944).

M 6, 234

Goodman, L. A., On the estimation of the number of classes in a population, Ann. Math. Statist. 20, 572 (1949).

M 11, 260

Gotaas, P., Formules de récurrence pour les semiinvariants à quelques lois de distribution à plusieurs variables, C. R. Acad. Sci., Paris 202, 619 (1936).

Z 13, 214

Gotaas, P., Formulae of recurrence for the semiinvariants at a class of frequency functions of more variables, Skand. Aktuarietidskr. 19, 200 (1936).

Z 15, 220

Gottschalk, V. H., Symmetrical bi-modal frequency curves, J. Franklin Inst. 245, 245 (1948).

M 9, 452

-Graf, U., Drei Nomogramme zur Bestimmung von Mittelwert-Toleranzen, Mitteilungsblatt Math. Statist. 2, 90 (1950).

M 12, 362

Guest, P. G., The fitting of polynomials by the method of weighted grouping, Ann. Math. Statist. 22, 537 (1951).

M 13, 481

Guldberg, A., On Poisson's frequency function, Skand. Aktuarietidskr. 14, 43 (1931). $\quad$ Z 1, 217

Guldberg, A., A remark on the Pearsonian frequency curves, Skand. Aktuarietidskr. 15, 82 (1932).

$\mathrm{Z} \mathrm{4}, 16$

Guldberg, A., Ist die normale Stabilität empirisch nachweisbar? Tôhoku Math. J. 3\%, 127 (1933).
Gumbel, E. J., Représentation des répartitions unimodales, unilatéralement limitées, $C . R$. Acad. Sci., Paris 196, 1268 (1933).

$\mathrm{Z}$ 6, 359

Gumbel, E. J., La dissection d'une répartition, Ann. Univ. Lyon A 11, 39 (1939). M 1, 247

Gumbel, E. J., Les valeurs de position d'une variable aléatoire, C. R. Acad. Sci., Paris 208, 149 (1939).

Z 20, 149

Gumbel, E. J., Elementare Ableitung der Momente für die Zahl der Überschreitungen, Mitteilungsblatt Math. Statist. 6, 164 (1954).

M 16, 270

Guttman, L., An inequality for kurtosis, Ann. Math. Statist. 19, 277 (1948).

М 9, 599

Haavelmo, T., The statistical implications of a system of simultaneous equations, Econometrica 11, 1 (1943).

M 4, 220

Haden, H. G., A note on the distribution of the different orderings of $n$ objects, Proc. Cambridge Philos. Soc. 43, 1 (1947).

M 8, 160

Hagstroem, K. G., Un problème du calcul stochastique, Försäkrings. Studier F. Lundberg, pp. 104127 (Stockholm, 1946).

M 8, 393

Hald, A., On the determination of the phagocytic power of leucocytes, Acta Pathologica et Microbiolog. Scand. XX, 64 (1943).

Haldane, J. B. S., The mean and variance of $\chi^{2}$, when used as a test of homogeneity, when expectations are small, Biometrika 31, 346 (1940).

M 1, 346

Haldane, J. B. S., The cumulants and moments of the binomial distribution, and the cumulants of $\chi^{2}$ for a $(n \times 2)$-fold table, Biometrika 31, 392 1940).

M 1, 346

Haldane, J. B. S., The cumulants of the distribution of the square of a variate, Biometrika 32, 199 (1941).

M 3, 170

Haldane, J. B. S., The fitting of binomial distributions, Ann. Eugenics 11, 179 (1941). M 4, 26

Haldane, J. B. S., The mode and median of a nearly normal distribution with given cumulants, Biometrika 32, 294 (1942).

M 4, 20

Haldane, J. B. S., Moments of the distributions of powers and products of normal variates, Biometrika 32, 226 (1942). M 4, 20

Hansmann, G. H., On certain non-normal symmetrical frequency distributions, Biometrika $\mathbf{2 6}$, 129 (1934).

Z 9, 220

Hart, B. I., Significance levels for the ratio of the mean square successive difference to the variance, Ann. Math. Statist. 13, 445 (1942). M 4, 165

Hartley, H. O., The range in random samples, Biometrika 32, 334 (1942).

M 4, 21

Hartley, H. O., The application of some commercial calculating machines to certain statistical calculations, Suppl. J. Roy. Statist. Soc. 8, 154 (1946).

M 9, 251

Hartley, H. O., A simplified form of Sheppard's correction formulae, Biometrika 3\%, 145 (1950).

M 12, 115

Hatke, M. A., A certain cumulative probability function, Ann. Math. Statist. 20, 461 (1949).

M 11, 41 
Havashi, C., Multidimensional quantification, Proc. Japan Acad. 30, 165 (1954)

M 16, 381

Hemelrijk, J., On the determination of confidence intervals and estimates for the coefficients of a straight line from a number of inaccurately observed points, Math. Centrum Amsterdam Rapport ZW-1949-013, 39 pp. (1949).

M 11, 445

$\checkmark$ Henning, H. J., (See U. Graf) Mitteilungsblatt Math. Statist. 2, 90 (1950).

-Henri, V. P., (See Z. Bay) Phys. Rev. 100, 1197 (1955).

Hirschman, A. O., On measures of dispersion for a finite distribution, J. Amer. Statist. Assoc. 38, 346 (1943).

M 5, 42

Hitcheock, H. P., The estimation of the probable error from successive and independent variances, Ballistic Research Lab. Report 193 (Aberdeen Proving Ground, Md., 1940).

M 12, 37

Hofmann, L., Über eine elementare Herleitung der Sheppardschen Korrekturen und eine prinzipielle Bemerkung über die letzteren, Statist. Vierteljschr. 6, 119 (1953).

M 15, 971

Hotelling, H., Experimental determination of the maximum of a function, Ann. Math. Statist. 12, 20 (1941).

M 2,232

-Hotelling, H., (See J. T. Chu) Ann. Math. Statist. 26, 593 (1955).

Hsu, C. T., The derivation of the fifth and sixth moments of the distribution of $b_{2}$ in samples from a normal population, Biometrika 31, 238 (1940).

M 1, 346

Hudimoto, H., Note on fitting a straight line when both variables are subject to error and some applications, Ann. Inst. Statist. Math., Tokyo \%, 159 (1956).

M 18, 242

Huhn, R., A trigonometrical method for computing the scales of statistical charts to improve visualization, J. Amer. Stat. Assoc. 26, 319 (1931).

Z 3, 18

Huron, R., Sur la répartition des décimales de rang donné dans les tables numériques, $C$. R. Acad. Sci., Paris 232, 299 (1951).

M 12, 427

-Irwin, J. O., Sampling moments of moments for a finite population, Ann. Eugenics 12, 138 (1944).

M 6, 162

Irwin, J. O., A unified derivation of some well-known frequency distributions of interest in biometry and statistics, J. Roy. Statist. Soc. Ser. A 118, 389 (1955).

M 1\%, 380

Isserlis, L., On the moment distributions of moments in the case of samples drawn from a limited universe, Proc. Roy. Soc. Lond. A 132, 586 (1931).

Z 2, 279

Jambunathan, M. V., The curve of population, $J$. Indian Math. Soc. 19, 151 (1932). Z 4, 157

$\checkmark$ Jecklin, H., Die elementaren Mittelwerte, Mitt. Verein. Schweiz. Versich. Math. 4\%, 123 (1947).

M 9, 81

Jeffreys, H., On the smoothing of observed data, Proc. Cambridge Philos. Soc. 33, 444 (1937).

Z 18, 34
Jeffreys, H., The correction of frequencies for a known standard error of observation, Monthly Not. Roy Astron. Soc. 98, 190 (1938). Z 18, 158 - Jersild, M., (See A. Hald) Acta Pathologica et Microbiologica Scandinavica xx, 64 (1943).

Johansen, N. P., Free functions, Mém. Inst. Géodésique Danemark 4, 30 pp. (1944). M \%, 462

Johnson, E., Estimates of parameters by means of least squares, Ann. Math. Statist. 11, 453 (1940).

M 2,233

Johnson, N. L., Systems of frequency curves generated by methods of translation, Biometrika $\mathbf{3 6}, 149$ (1949).

M 11, 527

-Johnson, N. L., (See F. N. David) Biometrika 3\%, $42(1950)$.

- Johnson, N. L., The moment problem for unimodal distributions, Ann. Math. Statist. 22, 433 (1951).

M 13, 119

Johnson, N. L., Systems of frequency curves derived from the first law of Laplace, Trabajos Estadist. 5, 283 (1955).

M 16, 1132

\ohnson, N. L., (See F. N. David) Metron 18, 77 (1956).

Jones, H. L., The use of grouped measurements, $J$. Amer. Statist. Assoc. 36, 525 (1941). M 4, 221

Jordan, Ch., Sur l'approximation d'une fonction à plusieurs variables, Acta Litt. Sci. Szeged. 8, 205 (1937).

Z 16, 365

Kamat, A. R., Moments of the mean deviation, Biometrika 41, 541 (1954).

M 16, 381

Kanner, H., (See Z. Bay) Phys. Rev. 100, 1197 (1955).

Kaplan, E. L., Tensor notation and the sampling' cumulants of $k$-statistics, Biometrika 39, 319 (1952).

M 14, 486

Kaplansky, I., A characterization of the normal distribution, Ann. Math. Statist. 14, 197 (1943).

M 4, 279

Kaplansky, I., A common error concerning kurtosis, J. Amer. Statist. Assoc. 40, 259 (1945). M g, 20

Kärsna, A., Über das System der einmodigen Häufigkeitskurven, Acta Comment. Univ. Tartuensis A 35, No 1, 65 pp. (1940).

M 4, 19

Kašanin, R., Le coefficient d'approximation moyenne et le coefficient de corrélation, Acad. Serbe. Sci. Publ. Inst. Math. 1, 71 (1947).

M 10, 552

Kendall, M. G., Note on the distribution of quantiles for large samples, Suppl. J. Roy. Statist. Soc. 7, 83 (1940).

M 2,231

Kendall, M. G., A recurrence relation for the semiinvariants of Pearson curves, Biometrika 32, 81 (1941).

M $\boldsymbol{2}, 231$

Kendall, M. G., (See J. O. Irwin) Ann. Eugenics 12, 138 (1944).

Kenney, J. F., Characteristic functions in statistics, Nat. Math. Mag. 1\%, 51 (1942).

M 4, 103

Kent, R. H., (See J. von Neumann) Ann. Math. Statist. 12, 153 (1941).

Kerawala, S. M., On bounds of skewness and kurtosis, Bull. Calcutta Math. Soc. 40, 41 (1948).

M 10, 134 
Kirkham, W. J., Moments about the arithmetic mean of a binomial frequency distribution, $A n n$. Math. Statist. 6, 96 (1935).

Z 1\%, 29

Kjellberg, B., Ein Momentenproblem, Ark. Mat. Astr. Fys. 29A, 33 pp. (1943).

M 6, 203

-Kloot, N. H., (See E. J. Williams) Australian J. Appl. Sci. 4, 1 (1953).

Knobloch, H., Funktionsgewichte in der Ausgleichsrechnung, Z. Angew. Math. Mech. 21, 315 (1941).

M \%, 462

Knoll, F., Zur Bruns-Hermiteschen Reihe in der mathematischen Statistik, S.-B. Akad. Wiss Wien 1935, 45 . (1935).

Z 11, 263

Knoll, F., Über Näherungsverfahren bei empirisch gegebenen Verteilungsfunktionen und damit verbundene Korrekturformeln, Deutsche Math. 7, 187 (1943).

M 8, 393

Kreis, H., Beitrag zur Theorie der Häufigkeitsfunktionen, Mitt. Verein. Schweiz. Versich. Math. 45, 239 (1945).

M $\boldsymbol{\%}, 461$

Krishnaswami Ayyangar, A. A., On the semiinvariants of two variates and their additive property, J. Indian. Math. Soc. 3, 1 (1938). $\quad$ Z 18, 320

Krishnaswami Ayyangar, A. A., The triangular distribution, Math. Student 9, 85 (1941) M 3, 171

Krishnaswami Ayyangar, G. V., Median of three populations. A simple construction, J. Annamalai Univ. 4, 62 (1935).

Z 11, 126

Krishna Iyer, P. V., The theory of probability distributions of points on a line, J. Indian Soc. Agric. Siatist. 1, 173 (1948).

M 11, 446

Krishna Iyer, P. V., The first and second moments of some probability distributions arising from points on a lattice and their applications, Biometrika $\mathbf{3 6}$, 135 (1949).

M 11, 607

Krishna Iyer, P. V., Difference equations of momentgenerating functions for some probability distributions, Nature 165, 370 (1950).

M 11, 446

Krishna Iyer, P. V., Further contributions to the theory of probability distributions of points on a line. III. J. Indian Soc. Agric. Statist. 4, $50(1952)$.

M 14, 297

- Kudō, T., On the decomposition of a bimodal distribution into two normal curves, J. Gakugei Tokushima U. Nat. Sci. Math. 6, 75 (1955).

M 1\%, 1102

Kuiper, N. H., Note on the fitting of a function to a large number of observations, Statistica (den Haag) 8, 1 (1954).

M 16, 497

Kullback, S., A note on Sheppard's corrections, Ann. Math. Statist. 6, 158 (1935).

Z 12, 175

Kullback, S., On certain distributions derived from the multinomial distribution, Ann. Math. Statist. 8, 127 (1937).

Z 18, 33

Kullback, S., On the Charlier type $B$ series, Ann. Math. Statist. 18, 574 (1947).

M 9, 234

Kupperman, M., On exact grouping corrections to moments and cumulants, Biometrika 39, 429 (1952).

M 14, 389

Lah, I., Analytical graduation of fertility rates, $J$. Amer. Statist. Assoc. 51, 461 (1956). M 18, 241

-Lawley, D. N., (See H. T. Hsu) Biometrika 31, 238 (1.940).
Lewis, W. T., A reconsideration of Sheppard's corrections, Ann. Math. Statist. 6, 11 (1935).

Z 11, 263

Lieblein, J., On moments of order statistics from the Weibull distribution, Ann. Math. Statist. 26, 330 (1955).

M 16, 1037

Liu, N., A new method for computing the mean difference, Essays and Papers in Memory of Fu SSu-Nien (The National Taiwan University, Taipei, 1952), pp. 339-356.

M 14, 888

Lomnicki, Z. A., The standard error of Gini's mean difference, Ann. Math. Statist. 23, 635 (1952).

M 53, 389

Lorenz, P., Über gewisse Funktionen, die in der mathematischen Konjunkturforschung eine grosse Rolle Spielen, J. Reine Angew. Math. 168, 170 (1932)

$\mathrm{Z} \mathbf{5}, 304$

Lorenz, P., Darstellung statistischer Übersichten mit zwei Eingängen durch orthogonale ganze rationale Funktionen (Flächendarstellung), Arch. Math. Wirtsch. Sozialforschg. 6, 57 (1940). M 6, 5

Lorenz, P., Herleitung der Näherungsformel von Laplace für die Binomialverteilung, ohne Grenzübergang, Z. Angew. Math. Mech. 29, 368 (1949).

M 11, 402

Lukacs, E., Applications of Faà di Bruno's formula in mathematical statistics, Amer. Math. Monthly 62, $340(1955)$.

M 16, 1037

Lukomski, J., On some properties of multidimensional distributions, Ann. Math. Statist. 10, 236 (1939).

M 1, 22

Lyttkens, E., On a class of conditional distributions, connected with some astronomical problems, Ark. Astronomi 1, 11 (1950).

M 12, 115

Lyttkens, E., On a class of multidimensional conditional characteristic functions and semi-invariants, Ark. Astronomi 1, 27 (1950).

M 12, 115

Lyttkens, E., A generalisation of the multidimensional A-series, Ark. Astronomi 1, 47 (1950).

M 1\%, 115

Lyttkens, E., Determination of unknown distributions by means of conditional frequency functions, Ark. Astronomi 1, 69 (1950).

M 12, 115

Majumer, D., Frequency curves and curve fitting, J. Assoc. Appl. Phys. Calcutta Univ. 1, 84 (1955).

M 1\%, 169

Mallows, C. L., Note on the moment-problem for unimodal distributions when one or both terminals are known, Biometrika 43, 224 (1956). M 17, 950

Marcantoni, A., Il principio dei minimi quadrati, U. Roma e. 1st. Naz. Alta. Mat. Rend. Mat. e. Appl. 3, 192 (1942).

M 8, 282

Mardessich, B., Sulle relazioni fra medie combinatorie e medie potenziate, Statistica (Bologna) 13, 77 (1953).

M 15, 45

Martin, E. S., On corrections for the moment coefficients of frequency distributions when the start of the frequency is one of the characteristics to be determined, Biometrika 26, 12 (1934). $\quad$ Z 9, 78

Martinotti, P., Di alcune recenti medie, Pont. Acad. Sci. Acta. 5, 113 (1941). M 3, 144

- Matsumura, N., (See T. Kudō) J. Gakugei Tokushima U. Nat. Sci. Math. 6, 75 (1955). 
Mattila, S., The decomposition of a series of observations by the method of iterated moving averages, Acad. Sci. Fennicae Ser. A Math.-Phys. No. 156, 16 pp. (1953).

M 15, 331

Maurin, J., Un mode de calcul général de la fonction de probabilité de moyennes, C. R. Acad. Sci., Paris 225, 1268 (1947).

M 9, 294

Maurin, J., Extension analytique d'un calcul de la fonction de probabilité de moyennes correspondant à une probabilité négative, C.R. Acad. Sci., Paris 226, 51 (1948).

M 9, 295

Maverick, L. A., Graphic presentation of standard deviation, J. Amer. Statist. Assoc. 2\%, 287 (1932).

Z 5, 174

McCarthy, P. J., Approximate solutions for means and variances in a certain class of box problems, Ann. Math. Statist. 18, 349 (1947). $\quad$ M 11, 41

Michalup, E., Über den Begriff "Exzess" in der mathematischen Statistik, Mitt. Verein. Schweiz. Versich. Math. 46, 231 (1946).

M 8, 393

Michalup, E., The characteristics, Bol. Acad. Ci. Fis. Mat. Nat. 11, 448 (1948). M 10, 50

Midutani, K. K., Ein neues Summenverfahren zur Berechnung der Momente, Mh. Math. Phys. 42, 49 (1935).

$\mathrm{Z}$ 11, 361

Milicer-Grizewska, H., An empirical curve and its generalisation, C. R. Soc. Sci. Varsovie 28, 79 (1936).

$\mathrm{Z} \mathrm{13,}, 410$

von Mises, R., An inequality for the moments of a discontinuous distribution, Skand. Aktuarietidskr. 22, 32 (1939).

M 1, 22; Z 21, 147

von Mises, R., On the asymptotic distribution of differentiable statistical functions, Ann. Math. Statist. 18, 309 (1947).

M 9, 194

Mitropol'skiľ, On determinants of the distribution of a series of natural numbers, Uspehi. Mat. Nauk. 10, 143 (1955).

M 1\%, 702

Mogno, R., Di un metodo di interpolazione statistica, Metron 12, 3 (1935).

$\mathrm{Z} \mathbf{1 1}, 315$

Montessus de Ballore, R., Statistique mathématique, les moments d'ordre nul de la fonction binomiale, Ann. Soc. Sci. Bruxelles A 51, 73 (1931). Z 2, 201

Montessus de Ballore, R., Statistique mathématique. Problèmes de degrés supérieurs, Ann. Soc. Sci. Bruxelles A 52, 22 (1932).

$\mathrm{Z}$ 4, 67

Montessus de Ballore, R., Statistique mathématique. Les moments partiels du second ordre de la fonction binomiale, Ann. Soc. Sci. Bruxelles A 52, 70 (1932).

$\mathrm{Z} \mathrm{4,} 358$

Mood, A. M., The distribution theory of runs, $A n n$. Math. Statist. 11, 367 (1940).

$\mathrm{M} \boldsymbol{2}, 228$

Mood, A. M., On the joint distribution of the medians in samples from a multivariate population, Ann. Math. Statist. 12, 268 (1941).

M 3, 172

Moriguti, S., A lower bound for a probability moment of any absolutely continuous distribution with finite variance, Ann. Math. Statist. P3, 286 (1952).

M 13, 853

Mortara, G., Misure ed indici delle disuguaglianze statistiche, Rend. Semin. Fis., Milano 8, 83 (1934).

Z 13, 360

Moyal, J. E., Approximate probability distribution functions for the sum of two independent variates, J. Roy. Statist. Soc. 105, 42 (1942).

M 4, 19

Muench, H., Discrete frequency distributions arising from mixtures of several single probability values, J. Amer. Statist. Assoc. 33, 390 (1938). Z 19, 73

Münzner, H., Úber die Bewertung der Potenzmomente, Mh. Math. Phys. 41, 375 (1934).

Z 10, 312

Nabeya, S., Note on the moments of the transformed correlation, Ann. Inst. Statist. Math., Tokyo 3, 1 (1951).

M 13, 478

Nabeya, S., Absolute moments in 2-dimensional normal distribution, Ann. Inst. Statist. Math., Tokyo 3, 2 (1951).

M 13, 570

Nabeya, S., Absolute moments in 3-dimensional normal distribution, Ann. Inst. Statist. Math., Tokyo 4, 15 (1952).

M 14, 569

- Nair, K. R., On a simple method of curve fitting, Sankhyā 6, 121 (1942).

M 4, 279

-Nair, K. R., A note on fitting of straight lines if both variables are subject to error, Sankhya $\mathbf{6}$, 331 (1943).

M 5, 126

Nanda, D. N., Distribution of the sum of roots of a determinantal equation under a certain condition, Ann. Math. Statist. 21, 432 (1950). M 12, 192

Narain, R. D., Some results on discriminant functions, J. Indian Soc. Agric. Statist. 2, 49 (1949).

M 12, 192

Nelder, J. A., The interpretation of negative components of variance, Biometrika 41, 544 (1954).

M 16, 381

- von Neumann, J., The mean square successive difference, Ann. Math. Statist. 12, 153 (1941).

M 3, 7

von Neumann, J., Distribution of the ratio of the mean square successive difference to the variance, Ann. Math. Statist. 12, 367 (1941).

M 4, 21

von Neumann, J., A further remark concerning the distribution of the ratio of the mean square successive difference to the variance, Ann. Math. Statist. 13, 86 (1942).

M 4, 22

Nicholson, C., A geometrical analysis of the frequency distribution of the ratio between two variables, Biometrika 32, 16 (1941).

M 2, 231

Nicholson; C., The probability integral for two variables, Biometrika 33, 59 (1943).

M 6, 161

Norris, N., The standard errors of the geometric and harmonic means and their application to index numbers, Ann. Math. Statist. 11, 445 (1940).

M 2, 228

Norton, K. A., Limits to the accuracy of estimated moment coefficients Sankhyā 3, 265 (1938).

Nybölle, H., On pseudo-analytical graduation, $J$. Inst. Actuar, 66, 63 (1935).

Z 12, 267

Odhnoff, W., Some studies of the characteristic functions and the semi-invariants of Pearson's frequency-functions, Försäkringsmatematiska Studier Tillägnade, (Filip Lundberg, Stockholm, 1946), pp. $168-179$.

M 8, 393

Oppenheim, A., (See A. C. Aitken) Proc. Roy. Soc. Edinburgh 51, 35 (1931). 
O'Toole, A. L., On symmetric functions and symmetric functions of symmetric functions, $A n n$. Math. Statist. 2, 101 (1931).

$\mathrm{Z}$ 4, 264

O'Toole, A. L., On symmetric functions of more than one variable and of frequency functions, $A n n$. Math. Statist. 3, 56 (1932).

$\mathrm{Z} 4,265$

O'Toole, A. L., A method of determining the constants in the bimodal fourth degree exponential function, Ann. Math. Statist. 4, 79(1933).

$\mathrm{Z} \boldsymbol{\gamma}, 220$

Ottestad, P., The exponential frequency function and frequency distributions, Metron 13, 51 (1937).

Z 16, 171

Ottestad, P., On the use of the factorial moments in the study of discontinuous frequency distributions, Skand. Aktuarietidskr. 22, 22 (1939).

M 1, 22; Z 21, 147

Ottestad, P., On Bernoullian, Lexis, Poisson and Poisson-Lexis series, Skand. Aktuarietidskr. 26, 15 (1943).

M $\boldsymbol{y}, 211$

Ottestad, P., On certain compound frequency distributions, Skand. Aktuarietidskr. 27, 32 (1944).

M $\boldsymbol{\gamma}, 211$

Pailloux, H., Sur un problème de répartition, $A n n$. Univ. Grenoble Sect. Sci. Math--Phys. 21, 123 (1946).

M 8, 160

- Pairman, E., On corrections for moment coefficients of limited range frequency distributions when there are finite or infinite ordinates and any slopes at the terminals of the range, Brometrika 12, 231 (1919).

Pankraz, O., Sur la désagrégation d'un groupe statistique, Publ. Fac. Sci. Univ. Masaryk 17\%, 1 (1933).

$\mathrm{Z} \%, 24$

Pârvulescu, C., Recherches statistiques sur les measures représentées par les notes donnés aux élèves, Bul. Fac. Sti. Cernauti 12, 22 (1939).

Patzer, H., Untersuchungen zur Methodik des Vergleichs zweier statistischer Reihen, (Dissertation: University of Göttingen, 1935) 37 pp. Z 14, 270

- Paulson, E., (See Z. W. Birnbaum) Psychometrika 15, $191(1950)$.

- Pearson, K., (See E. Pairman) Biometrika 12, 231 (1919).

Pearson, K., On the parent population with independent variates which gives the minimum value of $\phi^{2}$ for a given sample, Biometrika $\mathbf{2 5 ,} 134$ (1933).

-Pearson, E. S., (See R. C. Geary) (Cambridge Univ. Press, 1938) 15 pp.

Pearson, E. S., Some aspects of the geometry of statistics. The use of visual presentation in understanding the theory and application of mathematical statistics, J. Roy. Statist. Soc. Ser. A 119, 125 (1956).

M 18, 606

Peek, R. L., Some new theorems on limits of variation, Bull. Amer. Math. Soc. 39, 953 (1933).

Z 8, 265

Pelzer, H., (See A. E. W. Austen), Nature 15\%, 693 (1946).

Peters, C. C., A new descriptive statistic: the para- bolic correlation coefficient, Psychometrika 11, 57 (1946).

M $\boldsymbol{\%}, 462$

Petrov, V. V., On the method of least squares and its extremal properties, Uspehi Matem. Nauk. 9, 41 (1954).

M 15, 971

Petrov, V. V., On the method of least squares and its extremal properties, Acad. Rep. Pop. Romîne. An. Romîno-Soviet. Mat.-Fiz. 8, 5 (1954).

M 16, 726

Petrov, V. V., Corrections to the paper, "On the method of least squares and its extremal properties", Uspehi Mat. Nauk. 11, 250 (1956).

M 1\%, 1101

Philipson, C., Explicit expressions for the first four moments of a truncated distribution defined by Pearson type VI, Skand. Aktuarietidskr. 39, 63 (1956).

M 18, 955

Picard, H. C., A note on the maximum value of kurtosis, Ann. Math. Statist, 22, 480 (1951).

M 13, 141

Pierce, J. A., A study of a universe of $n$ finite populations with application to moment-function adjustments for grouped data, Ann. Math. Statist. 11, 311 (1940).

M 2,109

Pierce, J. A., Correction formulas for moments of a grouped-distribution of discrete variates, J. Amer. Statist. Assoc. 38, 57 (1943).

M 4, 221

Pitman, E. J. G., On the derivatives of a characteristic function at the origin, Ann. Math. Statist. 2\%, 1156 (1956).

M 18, 955

Pizzetti, E., Betrachtungen über die Messung der Variabilität vermittels der mittleren Differenz nach Gini, Arch. Rassenbiol. 34, 321 (1941). Z 24, 160

Plackett, R. L., A historical note on the method of least squares, Biometrika 36, 458 (1949).

M 11, 445

Quenouille, M. H., A relation between the logarithmic, Poisson, and negative binomial series, Biometrics 5, 162 (1949).

M 10, 722

Quenouille, M. H., On a method of trend elimination, Biometrika 36, 75 (1949). M 11, 674

Quensel, C. E., Truncated normal curves and correlation distributions, Lunds Univ. Arsskrift. N.F. 36, 17 pp. (1940).

M $\boldsymbol{2}, 231$

Quensel, C. E., Studies of the logarithmic normal curve, Skand. Aktuarietidskr. 28, 141 (1945).

M $\boldsymbol{\gamma}, 211$

Raiford, T. E., Skewness of combined distributions, J. Amer. Statist. Assoc. 3\%, 391 (1942). M 4, 20

Rajalakshman, D. V., On the extreme values of samples taken from a rectangular population, Math. Student 9, 103 (1941).

M 4, 21

Rao, C. R., On bivariate correlation surfaces, Science and Culture 8, 236 (1942).

M 5,126

Rao, C. R., Markoff's theorem with linear restrictions on parameters, Sankhyā $\boldsymbol{\gamma}, 16$ (1945).

M \%, 132

Rao, C. R., Generalisation of Markoff's theorem and tests of linear hypotheses, Sankhyā y, 9 (1945).

M $\%, 132$

Rao, C. R., On the mean conserving property, Proc. Indian Acad. Sci. Sect. A 23, 165 (1946). M 8, 40 
Rao, C. R., A general theory of discrimination when the information about alternative population distributions is based on samples, Ann. Math. Statist. 25, 651 (1954).

M 16, 380

Rao, C. R., Analysis of dispersion for multiply classified data with unequal numbers in cells, Sankhyā 15, 253 (1955).

M 1\%, 277

- Rasch, G., (See A. Hald) Acta Pathologica et Microbiologica Scandinavica xx, 64 (1943).

Reiersöl, O., Measures of departure from svmmetry, Skand. Aktuarietidskr. 2\%,229 (1944). M $\%, 211$

Richter, H., Zur Gaussischen Verteilung im ndimensionalen Raume, Z. Angew. Math. Mech. 29, 161 (1949).

M 11, 258

Rider, P. R., The third and fourth moments of the generalized Lexis theory, Metron 12, 185 (1934).

Z 11, 263

Rietz, H. L., Some remarks on mathematical statistics, Science \%4, 82 (1931).

$\mathrm{Z} 2,278$

Rietz, H. L., On the Lexis theory and the analysis of variance, Bull. Amer. Math. Soc. 38, 731 (1932).

Z 6, 23

Riordan, J., Inversion formulas in normal variable mapping, Ann. Math. Statist. 20, 417 (1949).

M 11, 41

Ríos, S., Problems of maxima and minima related to inference in finite populations, Trabajos Estadistica 6, 3 (1955).

M 1\%, 503

Risser, R., Note relative aux surfaces de probabilités, Assoc. Actuair. Belges Bull. No. 53, 5 (1948).

M 10, 312

Risser, R., Essai sur les courbes de distribution statistique, Assoc. Actuair. Belges Bull. No. 54, 41 (1948).

M 10, 386

Risser, R., Note relative aux surfaces de probabilités, J. Soc. Statist. Paris 89, 381 (1948). M 10, 722

Risser, R., Essai sur les courbes de distribution statistique, J. Soc. Statist. Paris 89, 288 (1948).

M 10, 722

Robb, R. A., The effect of change of origin in type A series, Fysiogr. Sällsk. Lund. Förh. 1, No. 8, 1 (1932).

$\mathrm{Z}$ 4, 359

Robb, R. A., The application of type A series to skew curves, Fysiogr. Sällsk. Lund. Förh. 1, No. 9, 1 (1932).

$\mathrm{Z}$ 4, 359

Robbins, R. B., Actuarial note: Osculatory curve of minimum degree using method of Lidstone's demonstration, Trans. Actuar. Soc. Amer. 35, 244 (1934).

Z 12, 411

Robson, D. S., Applications of the $k_{4}$ statistic to genetic variance component analyses, Biometrics 12, 433 (1956).

M. 18, 708

Rodrigues, M., On an extension of the concept of moment with applications to measures of variability, general similarity, and overlapping, Ann. Math. Statist. 16, 74 (1945).

M 6, 234

$\checkmark$ Rogers, C. A., (See N. L. Johnson) Ann. Math. Statist. 22, 433 (1951).

Romanovsky, V., Sulle regressioni multiple, Giorn. 1st Ital. Attuari. 2, 161 (1931).

Z 1, 217

Romanovsky, V., Note on the method of moments, Biometrika 28, 188 (1936).
Ruben, H., On the moments of order statistics in samples from normal populations, Biometrika 41, 200 (1954).

M 16, 153

Sakamoto, H., On the distributions of the product and the quotient of the independent and uniformly distributed random variables, Tôhoku Math. $\dot{J}$. 49, 243 (1943).

M 8, 523

Salvemini, T., Sulla correzione dei momenti empirici di una distribuzione statistica, Giorn. 1st Ital. Attuari. 10, 69 (1939).

Z 22, 63

Salvemini, T., Di uno scarto trigonometrico medio, nel caso delle serie cicliche, Atti Secondo Congresso. un Mat. Ital. Bologna, pp. 657-671 (Edizioni Cremonense, Rome, 1942).

M 8, 474

Salvemini, T., Gli indici di connessione nel caso di variabili casuali normali e considerazioni sulla graduatoria tra indici di connessione e indici di concordanza, Statistica (Bologna) 15, 77 (1955).

M 16, 1037

Šamonil, F., Remark to the summation-formulas of the Lubbock's type, Aktuár. Védy 4, 120 (1934).

$\mathbf{Z}$ 9, 220

Samuelson, P. A., Fitting general Gram-Charlier series, Ann. Math. Statist. 14, 179 (1943). M 4, 279

Sarkadi, K., Choice of intervals for grouping of data, Magyar Tud. Akad. Alkalm. Mat. Int. Közl. 2, 299 (1954).

M 16, 380

Sarkadi, K., On Sheppard's correction concerning the mean deviation, Magyar Tud. Akad. Alkalm. Mat. Int. Közl. 3, 183 (1955).

M 1\%, 871

Satterthwaite, F. E., Synthesis of variance, Psychometrika 6, 309 (1941).

M 3, 172

Satterthwaite, F. E., Generalized Poisson distribution, Ann. Math. Statist 13, 410 (1942). M 4, 163

Sawkins, D. T., The use of cumulative graphs for estimation of means, higher moments, etc., Metron 13, 33 (1938).

$\mathrm{Z}$ 20, 148

Sawkins, D. T., Remarks on goodness of fit of hypotheses and on Pearson's $\chi^{2}$ test, J. Proc. Roy. Soc., New South Wales 75, 85 (1941). M 3, 175 von Schelling, H., Die Konzentration einer Verteilung und ihre Abhängigkeit von den Grenzen des Variationsbereiches, Metron 11, 3 (1934). $\quad$ Z 10, 173

Schneider, S., Sur l'ajustement des courbes à branches limitées, J. Soc. Statist. Paris 89, 218 (1948).

M 10, 721

Seal, K. C., A note on moments of order statistics from svmmetrical populations, Calcutta Statis. Assoc. Bull. 6, 91 (1955).

M 1\%, 503

Selberg, H. L., On an inequality in mathematical statistics, Norsk Mat. Tidsskr. 24, 1 (1942)

M 8, 199

Selberg, H. L., On the corrections for grouping, Skand. Aktuarietidskr. 30, 179 (1947). M 10, 721

Sengupta, J. M., A note on adjustments for first and second moments in a grouped frequency distribution split up into subsections, Sankhyā 6, 413 (1944).

M 5, 208

Shannon, S., Comparative aspects of the point binominal polygon and its associated normal curve of error, Record Amer. Inst. Actuar. 31, 208 (1942).

M 4, 279 
Shenton, L. R., On the efficiency of the method of moments and Neyman's type A distribution, Biometrika 36, 450 (1949).

M 11, 445

Sheppard, W. F., The calculation of the moments of a frequency distribution, Biometrika 5, 450 (1907).

Sherman, J., The use of orthogonal polynomials in curve fitting and regression analysis, Proc. Ind. Comp. Seminar, Sept. 1950, pp. 78-80 (IBM Corp., N.Y. 1951).

M 13, 481

Shone, K. J., Relations between the standard deviation and the distribution of range in non-normal populations, J. Roy. Statist. Soc., Ser. B 11, 85 (1949).

M 11, 260

Shrivastava, M. P., Bi-variate correlation surfaces, Science and Culture 6, 615 (1941). M 5, 126

- Shrivastava, M. P., (See K. R. Nair) Sankhyā 6, 121 (1942).

Sichel, H. S., The method of frequency-moments and its application to type VII populations, Biometrika 36, 404 (1949).

M 11, 733

Siegel, I. H., Note on a common statistical inequality, J. Amer. Statist. Assoc. 38, 217 (1943).

M 4, 220

Silverstone, H., (See A. C. Aitken) Proc. Roy. Soc., Edinburgh A 61, 186 (1942).

Silverstone, H., A note on the cumulants of Kendall's S-distribution, Biometrika 3\%, 231 (1950).

M 12, 344

Simaika, J. B., Interpolation for fresh probability levels between the standard table levels of a function, Biometrika 32, 263 (1942).

M 4, 20

Simaika, J., Sur une mesure de la dispersion d'une distribution de directions, Bull. Acad. Polon. Sci. Ci. III 4, 753 (1956).

M 18, 679

Simonett, J., Beiträge zur Ausgleichung von Massenerscheinungen nach der Methode von King, Mitt. Verenig. Schweiz. Versich. Math. H 28, 91 (1933)

$\mathrm{Z} \mathbf{8}, 315$

Singleton, R. R., A method for minimizing the sum of absolute values of deviations, Ann. Math. Statist. 11, 301 (1940).

M 2,109

Sittig, J., Superposition of two frequency distributions, Statistica (Rijswijk) 2, 206 (1948).

M 11, 258

Skellam, J. G. The frequency distribution of the difference between two Poisson variates belonging to different populations, J. Roy, Statist. Soc. 109, 296 (1946).

M 8, 592

Skellam, J. G. A probability distribution derived from the binomial distribution by regarding the probability of success as variable between the sets of trials, J. Roy. Statist. Soc., Ser. B, 10, 257 (1948).

M 10, 463

Skellam, J. G. The distribution of the moment statistics of samples drawn without replacement from a finite population, J. Roy. Statist. Soc., Ser. B, 11, 291 (1949).

M 11, 607

Smirnoff, N. Sur les écarts de la courbe de distribution empirique, Rec. Math. 6, 3 (1939). .M 1, 246

Smirnoff, $\mathrm{N}$. On the estimation of the discrepancy between empirical curves of distribution for two independent samples, Bull. Math. Univ. Moscou, 2, No. 2, 16 pр. (1939).

M 1,345
Smirnov, N. Table for estimating the goodness of fit of empirical distributions, Ann. Math. Statist. 19, 279 (1948).

M 9, 599

Stange, K. Über die Verteilungsdichte der Messoder Beobachtungsfehler eines dreidimensionalen Punktraumes, Z. Angew. Math. Mech. 28, 235 (1948).

M 10, 134

Stange, K. Über das Ausgleichen einer fehlerhaften linearen Punktreihe bei korrelativer Verknüpfung. der Messfehler, Mitteilungsblatt Math. Statist. 4, 48 (1952).

M 13, 963

- Stephan, F. F. (See W E. Deming) Ann. Math. Statist. 11, 427 (1940).

Stephan, F. F., An iterative method of adjusting sample frequency tables when expected marginal totals are known, Ann. Math. Statist. 13, 166 (1942).

M 4, 24

Strömgren, B., Tables and diagrams for dissecting a frequency curve into components by the halfinvariant method, Skand. Aktuarietidskr. 1\%, 7 (1934). Z 8, 266

Stuart, A., The cumulants of the first $n$ natural numbers, Biometrika 3\%, 446 (1950). M 12, 344

Sukhatme, P. V., Moments and product moments of moment-statistics for samples of the finite and infinite populations, Sankhyā 6, 363 (1944). M 6, 8

Sukhatme, P. V., Measurement of observational errors in surveys, Rev. Inst. Internat. Statistique 20, 121 (1952).

M 15, 141

Sundrum, R. M., Moments of the rank correlation coefficient $\tau$ in the general case, Biometrika 40, 409 (1953).

M 15, 331

Sundrum, R. M., A further approximation to the distribution of Wilcoxon's statistic in the general case, J. Roy. Statist. Soc., Ser. B, 16, 255 (1954).

M 16, 1037

Szatrowski, Z., Calculating the geometric mean from a large amount of data, J. Amer. Statist. Assoc. 41, 218 (1946).

M $\%, 462$

Teatini, U., Interpolazione di serie cicliche, Statistica (Milano) 8, 125 (1948).

M 11, 530

Teodorescu, C. C., Nouvel emploi des moments d'inertie aux questions statistiques, Actes Congr. Interbalkan Math. pp. 189-195 (Athènes, 1935).

Z 15, 33

Thesen, G., Über periodische Funktionen, ihre Observation und Ausgleichung, Skand. Aktuarietidskr. 23, 168 (1940).

M 2,232

Thompson, W. R., Use of moving averages and interpolation to estimate median-effective dose, Bacteriological Rev. 11, 115 (1947). M 11,733

Tintner, G., The distribution of the variances of variate differences in the circular case, Metron 1\%, 43 (1955).

M 16, 1132

Toledo Piza, A. P., Representative values of a distribution. Indices of dispersion, Anais Acad. Brasil Ci. 28, 209 (1946).

M 8, 447

Tomita, J., On binomial distribution, Mem. Coll. Sci. Kyoto A 15, 195 (1932).

$\mathrm{Z} \mathrm{5,} 212$

Toranzos, F. I., A system of frequency curves which generalizes that of Pearson, Revista Fac. Ci. Econ. Univ. Cuyo 1, 7 pp. (1949).

M 11, 190 
Toranzos, F. I., An asymmetric bell-shaped frequency curve, Ann. Math. Statist. 23, 467 (1952).

M 14, 189

Truksa, L., The simultaneous distribution in samples of mean and standard deviation, and of mean and variance, Biometrika 31, 256 (1940). M 2,109

Tukey, J. W., An inequality for deviations from medians, Ann. Math. Statist. 1\%, 75 (1946).

M $\boldsymbol{\%}, 462$

Tukey, J. W., Some sampling simplified, J. Amer. Statist. Assoc. 45, 501 (1950).

M 12. 725

$\checkmark$ Tukey, J. W., (See M. F. Freeman) Ann. Math. Statist. 21, 607 (1950).

Tukey, J. W., Variances of variance components. III. Third moments in a balanced single classification, Ann. Math. Statist., 28, 378 (1957).

M 18, 955

Uggè, A., Di alcune proprietà dei momenti della curva di probabilità e degli indici di normalità, Pont. Acad. Sci. Acta 6, 229 (1942). M 10, 201

Vaidyanathaswamy, R., On the arithmetico-logical symmetric functions of $n$ attributes, Proc. Indian Acad. Sci., Sect. A 2, 54 (1935).

$\mathrm{Z}$ 12, 113

Vajda, S., On the constituent items of the reduction and the remainder in the method of least squares, Ann. Math. Statist. 16, 381 (1945). M g, 316

Van Ijzeren, J., The theoretical aspect of least squares, Statistica (Rijswijk) 8, 21 (1954).

M 16, 385

Van Uven, M. J., Extension of Pearson's probability distributions to two variables-I, II Indagationes Math. 9, 477 and 578 (1947).

M 9, 363

Van Uven, M. J., Extension of Pearson's probability distributions to two variables-III, IV, Indagationes Math. 10, 12 and 62 (1948). $\quad$ M 9, 452

Vatnsdal, J. R., Minimal variance and its relation to efficient moment tests, Ann. Math. Statist. 1\%, 198 (1946).

M 8, 40

Vaughan, H., Further enquiries into the summation method of graduation, J. Inst. Actuar. 66, 463 (1935).

$\mathrm{Z} \mathbf{1 3}, 70$

Villars, D. S., A significance test and estimation in the case of exponential regression, Ann. Math. Statist. 18, 596 (1947).

M 9, 363

Vodička, V., Fonctions symétriques et leur aplication dans la statistique mathématique, Acta Fac. Nat. Univ. Carol., Prague No. 174, 17 (1947).

M 9, 599

Wald, A., Long cycles as a result of repeated integration, Amer. Math. Monthly 46, 136 (1939).

$\mathrm{Z} \mathbf{2 1}, 45$

Wald, A., The fitting of straight lines if both variables are subject to error, Ann. Math. Statist. 11, 285 (1940).

M 2,108

Weaver, C. L., A simple analytic proof of a general $\chi^{2}$ theorem, Amer. Math. Monthly 54, 529 (1947).

M 9, 195
Weibull, W., New methods for computing parameters of complete or truncated distributions, Flygtekn Försöksanstalt Rep. 58, 21 pp. (1955). M 1\%, 278

Weida, F. M., On measures of contingency, Ann. Math. Statist. 5, 308 (1934).

Z 11, 33

Wilkins, J. E., A note on skewness and kurtosis, Ann. Math. Statist. 15, 333 (1944).

M 6, 91

- Williams, E. J., Interpolation in a series of correlated observations, Australian J. Appl. Sci. 4, 1 (1953).

M 14, 1104

Williams, E. J., A method of analysis for double classifications, Australian J. Appl. Sci. 4, 357, (1953).

M 15, 450

Williams, J. D., Moments of the ratio of the mean square successive difference to the mean square difference in samples from a normal universe, $A n n$. Math. Statist. 12, 239 (1941).

M 3, 7

Wilson, E. B., On the proof of Sheppard's corrections, Nat. Acad. Sci. USA, Proc. 13, 151 (1927).

Wintner, A. Factorial moments and enumerating distributions, Skand. Aktuarietidskr, 32, 63 (1949).

M 11, 173

Wise, M. E., The effect of rounding off in samples, Statistica (den Haag) 8, 169 (1954.) M 16, 132

Wishart, J., A comparison of the semi-invariants of the distributions of moment and semi-invariant estimates in samples from an infinite population, Biometrika 25, 52 (1933).

Z \%, 124

Wishart, J., Moment coefficients of the $k$-statistics in samples from a finite population, Biometrika 39, 1 (1952).

M 14, 296

Wishart, J., The factorial moments of the distribution of joins between line segments, Biometrika 41, 555 (1954).

M 16, 381

Wisniewski, J. K., A problem in least squares, $A n n$. Math. Statist. 8, 145 (1937).

Z 18, 35

Wisseroth, K., Die günstigste Verteilungsbreite, ein neues Streuungsmass, Z. Angew Math. Mech. 25/2\%, 126 (1947).

M 9, 294

Wold, H., A study on the mean difference, concentration curves and concentration ratio, Metron 12, 39 (1935).

$\mathrm{Z} \mathbf{1 1}, 315$

Zappa, G., (See C. Gini), Metron 13, 21 (1938). Zaycoff, R., Über die Zerlegung statistischer Zeitreihen in drei Komponenten, Publ. Statist. Inst. Econ. Res. No. 4, 22 pp. (State Univ. of Sofia, 1936).

$\mathrm{Z} \mathbf{1 6}, 172$

Ziaud-Din, M., Expression of the $k$-statistics $k_{9}$ and $k_{10}$ in terms of power sums and sample moments, Ann. Math. Statist. 25, 800 (1954). M 16, 381

Ziaud-Din, M., On contributions to sampling distribution from symmetric functional point of view, Bull. Inst. Internat. Statist. 24, 207 (1954).

M 16, 1132

Zoch, R. T., Invariants and covariants of certain frequency curves, Ann. Math. Statist. 5, 124 (1934).

Z 9, 220

Zoch, R. T., Some interesting features of frequency curves, Ann. Math. Statist. 6, 1 (1935). Z 11, 361

(Paper 66B1-69) 